\title{
Orígenes altiplánicos de la Fase Toconce
}

\author{
Victoria CASTro $^{1}$, Carlos Aldunate ${ }^{2}$ y José Berenguer ${ }^{2}$
}

\section{Introducción}

Tradicionalmente, la región del Loa Superior (Figura 1) ha sido vinculada a los desarrollos culturales del desierto o complejos "atacameños” (Latcham 1938; Rydén 1944; Mostny 1949; Pollard 1970; Spahni 1964). No hace mucho, sin embargo, sostuvimos que los ocupantes de Likan (Toconce) -un sitio de chullpa situado en la sección sudoriental de esta región o cuenca del río Saladoprocedían del altiplano boliviano (Castro et al. 1979a). Quizás bastarían las evidencias presentadas en ese escrito para dar por sentado el hecho, pero estimamos que el "problema de los orígenes de esta ocupación tiene muchas aristas, imponiéndose una investigación histórica más acuciosa. Por ejemplo, si se trata de una población altiplánica ¿por qué, entonces, sus ajuares funerarios incluyen elementos atacameños"? ¿Qué hace a esta ocupación diferente a la de los complejos locales? ¿Puede tratarse de grupos "atacameños" altiplanizados? ¿Dispone esta población altiplánica de ancestros en la región? Si vienen del altiplano, ¿de dónde, específicamente? Es indispensable contestar interrogantes como estas antes de abordar cuestiones de carácter más sustantivo como aquellas relativas al proceso de adaptación cultural que hizo posible el desenvolvimiento de estas comunidades en la Subárea Circumpuneña. Y para esto, consideramos necesario el acopio de nuevas y más concluyentes evidencias, así como el análisis crítico de algunos argumentos y la formulación de otros.

El hallazgo de varios sitios con características similares a Likan, en diversos puntos de la cuenca del Salado, muestra claramente la distribución subregional alcanzada por la Fase Toconce, una pequeña sociedad de pastores cultivadores que, hacia $900 \mathrm{DC}$, irrumpen en la prehistoria regional y cuya filiación

1 Departamento de Antropología, Universidad de Chile. Casilla 3687, Santiago, CHILE.

2 Museo Chileno de Arte Precolombino. Casilla 3687, Santiago, CHILE. cultural es aquí materia de un renovado análisis. ${ }^{3}$ Sostenemos que la Fase Toconce es "altiplánica" en dos sentidos diferentes, aunque no excluyentes entre sí: en primer lugar, porque sus más remotos orígenes estarían en el altiplano septentrional, al parecer en alguna región circundante al Lago Titicaca; y en segundo lugar, porque aparentemente formó parte de una sociedad cuyo territorio no sólo comprendía a las quebradas altas de la cuenca del Salado, sino también a la sección meridional del altiplano de Lípez. Pese a las correlaciones que más adelante establecemos entre el Salado y las provincias de Lípez, en este trabajo nos hacemos cargo únicamente de la primera de estas afirmaciones, dejando las implicancias funcionales de la segunda para otro trabajo que se halla en preparación (Aldunate et al. Ms).

El presente artículo se inicia con una discusión acerca de cómo las investigaciones arqueológicas han ido desechando la supuesta filiación "atacameña" de algunos sitios y materiales del Período Intermedio Tardío del Loa Superior, en favor de una filiación "altiplánica". Continúa con una presentación de las evidencias arqueológicas que definen y caracterizan a la Fase Toconce, analizándose su lugar en la secuencia local. Y concluye con un estado actual del problema, en el que se pasa revista a los fundamentos que existen para sostener un origen altiplánico de esta fase arqueológica.

\section{Una perspectiva histórica del problema}

Hace poco más de un cuarto de siglo, todavía se incluía bajo el rótulo de "zona atacameña chilena" a un gran territorio del interior de la entonces Provincia de Antofagasta (Schaedel 1957). Como en esa época la palabra "atacameño" conservaba aún mucho del significado étnico y cultural que antaño le dieran Latcham (1938), Oyarzún (1935),

\footnotetext{
3 Esta investigación ha sido posible gracias al financiamiento otorgado por el Departamento de Desarrollo de la Investigación de la Universidad de Chile, proyectos S-459-791 y S-1435-8213.
} 
Uhle (1913) y otros pioneros de la antropología del norte de Chile, incluir a una región en esta "zona atacameña" implicaba un compromiso conceptual que iba mucho más allá que una simple adscripción geográfica. ${ }^{4}$ Aunque en franco retroceso, la idea que prevalecía en ese momento postulaba un territorio bastante extenso para la así llamada "cultura atacameña" y ese territorio incluía, por cierto, al ámbito geográfico de lo que hoy conocemos como Fase Toconce (Mostny 1949; Le Paige 1959; Spahni 1963). Curiosamente, a nadie parece haber extrañado entonces que los sitios arqueológicos tardíos de la región del Loa Superior fueran calificados de "atacameños" (Latcham 1938; Bennett 1946; Mostny 1949), en circunstancias que la población indígena residente allí hoy en día ha sido definida por algunos autores como "no atacameña" y quechua o aymara parlante (p.e., Hanson 1926: 372). ${ }^{5}$ Es particularmente digna de hacer notar la agudeza de Hanson, quien, ya en la tercera década de este siglo, se planteaba el problema de la secuencia de la ocupación humana tardía en la cuenca del Salado y sus diferentes orígenes étnicos.

\section{"Several things seem to suggest that the present inhabitants (de Ayquina, Toconce y Caspana) are not descendants of the Atacamenians who smelted copper on the vega of Turi and the banks of the rio Toconce before the advent of Almagro but that, on the contrary, the original indigenous stock disappeared in some way and the ancestors of the present inhabitants came over from Bolivia" (Hanson 1926: 377).}

Pero en una época en que el prisma que regía la antropología del norte de Chile rara vez dejaba ver otra cosa que no fuera "atacameños", el interesante

4 En arqueología, la palabra "atacameño" se usa hoy para denominar a la sucesión de pueblos prehistóricos que se desenvolvieron exclusivamente en las "quebradas, oasis y territorios andinos que rodean la plataforma puneña trasandina (...) o ámbito geográfico atacameño" (Bittmann et al. 1978: 5). El único alcance étnico que el término "atacameño" conserva en la antropología tiene que ver con la pequeña etnia que los españoles encontraron habitando la Región del Salar de Atacama en el siglo XVI. Para una discusión sobre la palabra “atacameño", ver Mostny (1969: 129), Orellana (1963a: 30-32) y Pollard (1970: 74-79).

5 Una idea similar se desprende de algunos pasajes de la obra de Bertrand (1895: 268-275) ya que, aun cuando sostiene que en Caspana viven indios atacameños, en un listado que presenta de los puntos ocupados por esta etnia en el sector andino de lo que hoy se conoce como Subárea Circumpuneña, no incluye a los pueblos de Toconce y Ayquina. problema de historia cultural planteado por Hanson no tenía mucho destino. Más adelante comentaremos su hipótesis a la luz de los datos actuales.

\section{Planteamientos en los años 50}

Poco a poco, sin embargo, las investigaciones arqueológicas de fines de la década del 50 en el Loa Superior comienzan a generar evidencias que entran en abierta contradicción con la idea vigente. Ya en las postrimerías de los años 40, en su monografía Ciudades atacameñas, Mostny (1949: 170-172) había descrito unos "torreones" del Pucara de Turi -a los que previamente Latcham (1938: 93-95) considerara silos y atribuyera al Período Chincha Atacameño-, comparándolos con las chullpa peruanas y bolivianas (Mostny 1949: 176). Varios años después, Nalle (1956: 27) insiste en esta idea, anunciando, además, el hallazgo de estructuras similares en Toconce. Pero es sólo a partir de 1957 que se vuelve a sugerir una presencia aymara o altiplánica en esta región supuestamente atacameña. Mostny y Naville (1957), por ejemplo, quienes estudiaron el sitio que hoy conocemos como Likan (Aldunate et al. 1982), señalan que las chullpa de Toconce recuerdan a las construcciones similares de los aymara del altiplano. Aunque poco después Mostny (1959) hace una breve reseña sobre las sepulturas en abrigos rocosos de este sitio y concluye que los contextos funerarios son típicamente atacameños, ese mismo año Le Paige (1959: 30) sostiene que las chullpa de Toconce son aymara y que su construcción no es obra de los atacameños. ${ }^{6}$ En opinión de Le Paige (1959: 107-108, 1963: 23), la zona atacameña fue reduciéndose paulatinamente y entre los siglos XIII y XVI los pueblos de Toconce, Ayquina y Caspana habrían sido ocupados pacíficamente por los "quechua-aymara" o "culturas del altiplano". En cambio Chiu Chiu, Río Grande y San Pedro de Atacama habrían permanecido como "atacameños" (Le Paige 1959: 113, 1963: 23).

\section{Planteamientos en los años 60}

Pero los aymara no fueron los únicos, al parecer, que redujeron la zona atacameña. También lo hicieron (y de manera drástica) los arqueólogos de la década siguiente. En efecto, los términos étnicos en que

6 En su diario de terreno Le Paige (Ms) señala: "Las ruinas consisten en unas treinta [sic] torres a la manera de chullpa de los aymara". 
había comenzado a desarrollarse el debate a fines de los años 50 y principios de los 60, quedaron súbitamente obsoletos cuando, como un tardío eco de la Mesa Redonda de Lima (1953), los acuerdos del Congreso Internacional de Arqueología de San Pedro de Atacama (1963: 199; Orellana 1963a: 30, 1963b: 29-31) recomendaron abandonar las categorías étnicas en la denominación de las culturas prehistóricas y sustituir la antigua denominación Cultura Atacameña por la de Complejo Cultural San Pedro. Aunque algunos autores continuaron hablando de atacameños o atacamas (Spahni 1963 y 1964; Le Paige 1965; Mostny 1969) y de fragmentos cerámicos Colla-Pacajes (Le Paige 1964), a la larga se impusieron los acuerdos de 1963 y su terminología de sitio-tipo (p.e., Núñez 1965b; Tarragó 1968).

En ese mismo Congreso (1963: 204), algunos arqueólogos sostuvieron que el "Complejo Cultural San Pedro es diferente de lo encontrado en Chiu Chiu", especialmente en lo que se refiere a las tabletas de rapé (Núñez 1963). Con posterioridad, esta impresión fue hecha extensiva a toda la Subregión del río Salado y tomando en cuenta a un mayor número de indicadores arqueológicos (Orellana 1965: 81). Núñez (1965b), por su parte, en su conocida síntesis de la prehistoria del norte de Chile, dio un tratamiento diferente a los materiales del Salar de Atacama y del Loa Superior, reafirmando la idea de que hay ciertas diferencias sustanciales entre ambas regiones.

El canon que se impuso en la arqueología del norte de Chile después de 1963 parece haber desalentado la tendencia que se insinuaba a fines de la década precedente, en orden a intentar la identificación étnica de los materiales arqueológicos más tardíos. La desaparición del debate que comenzaba a gestarse en torno a esto en las postrimerías de los años 50, es buena prueba de ello. Toconce 1 (Likan), por ejemplo, el mismo sitio de chullpa que Mostny y Naville (1957) compararan con otros sitios similares de los "aymara del altiplano" y que Le Paige (1959-1963) no dudara en atribuir a los "quechua-aymara" o a las "culturas del altiplano", fue descrito por Núñez (1965a: 10) simplemente como un cementerio de chullpa del Período Agroalfarero Tardío (preinca), eludiendo el problema de la identidad étnica. Ni siquiera fue mencionado en la citada síntesis sobre el norte de Chile (Núñez 1965b). Orellana (1968), en tanto, mantuvo su idea sobre las diferencias que él ve entre el desarrollo cultural del río Salado y el producido en la Región del Salar de Atacama.
No obstante, los únicos elementos que considera ajenos en el Salado son algunos tipos cerámicos propios del Complejo San Pedro, ciertos rasgos de diferente índole que atribuye a Tiahuanaco Expansivo y unos pocos fragmentos cerámicos que identifica como incaicos (Orellana 1968: Figs. 1 y 2) o inca regional (Orellana et al. 1969: 117). Incluye dentro de estos elementos foráneos a los "edificios incásicos" de Turi (Orellana 1968: 30). En cambio, sus referencias a Toconce son escasas e indirectas (1968: 24) y, al igual que Núñez, tampoco aborda el problema representado por la presencia de chullpa y otros elementos altiplánicos tardíos en la cuenca del río Salado.

\section{Planteamientos en los años 70}

No muy diferentes son los resultados que a principios de los 70 comienza a entregar la misión científica de la Universidad de Columbia (1966-68) que, bajo la dirección de E. Lanning, llevó a cabo una amplia investigación arqueológica en el Loa Medio, con algunas incursiones en el Loa Superior. En su tesis de doctorado, Pollard (1970) -entonces uno de los colaboradores de Lanning- da a conocer un complejo regional del Loa Medio denominado Lasana. La segunda fase de este complejo se inscribe en el Período Intermedio Tardío (800-1470 DC). Según Pollard, Lasana II también está presente en la cuenca del Salado, específicamente en tres sitios: en el Pucara de Turi (RAnL-300), en un sitio situado a unos $300 \mathrm{~m}$ al norte de los baños de Turi (RAnL-351) y en el sitio Topaín (RAnL-299). Curiosamente, Pollard parece no percatarse de los problemas implicados por la presencia de chullpa en el sector más alto del Pucara de Turi (1970: 261). Similarmente, a pesar de que conoció Toconce (Pollard 1970: 33, Fig. 3) y que es difícil que no haya tenido referencias de sus chullpa, no existe en su trabajo ninguna mención a ellas y tampoco algún planteamiento que contemple la coexistencia en la Subregión del río Salado del Complejo Lasana II con alguna fase altiplánica. Sobre la base de datos bibliográficos, sin embargo, reconoce que Toconce (Likan) es un asentamiento contemporáneo con el complejo Lasana (1970: 34 y Fig. 67).

Sea por efectos del avance de las investigaciones en el norte de Chile, sea como una consecuencia de las influyentes ideas de Murra (1972) y su modelo de "complementariedad ecológica" en los Andes, o por ambas cosas a la vez, lo cierto es que la arqueología de la Subárea Circumpuneña y la del río Loa en 


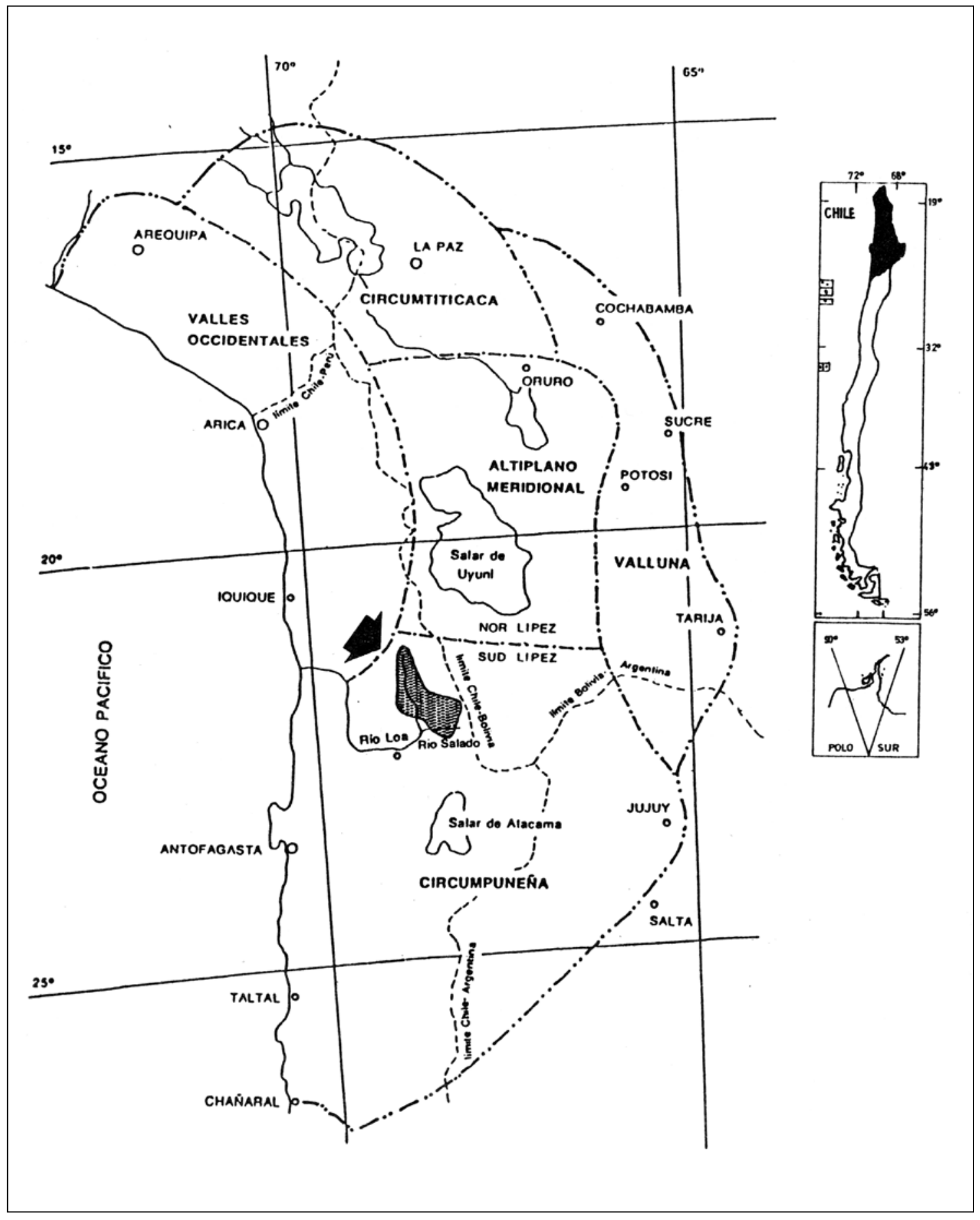

Figura 1. Región del Loa Superior en el Area Centro Sur Andina (Castro et al. 1984). 


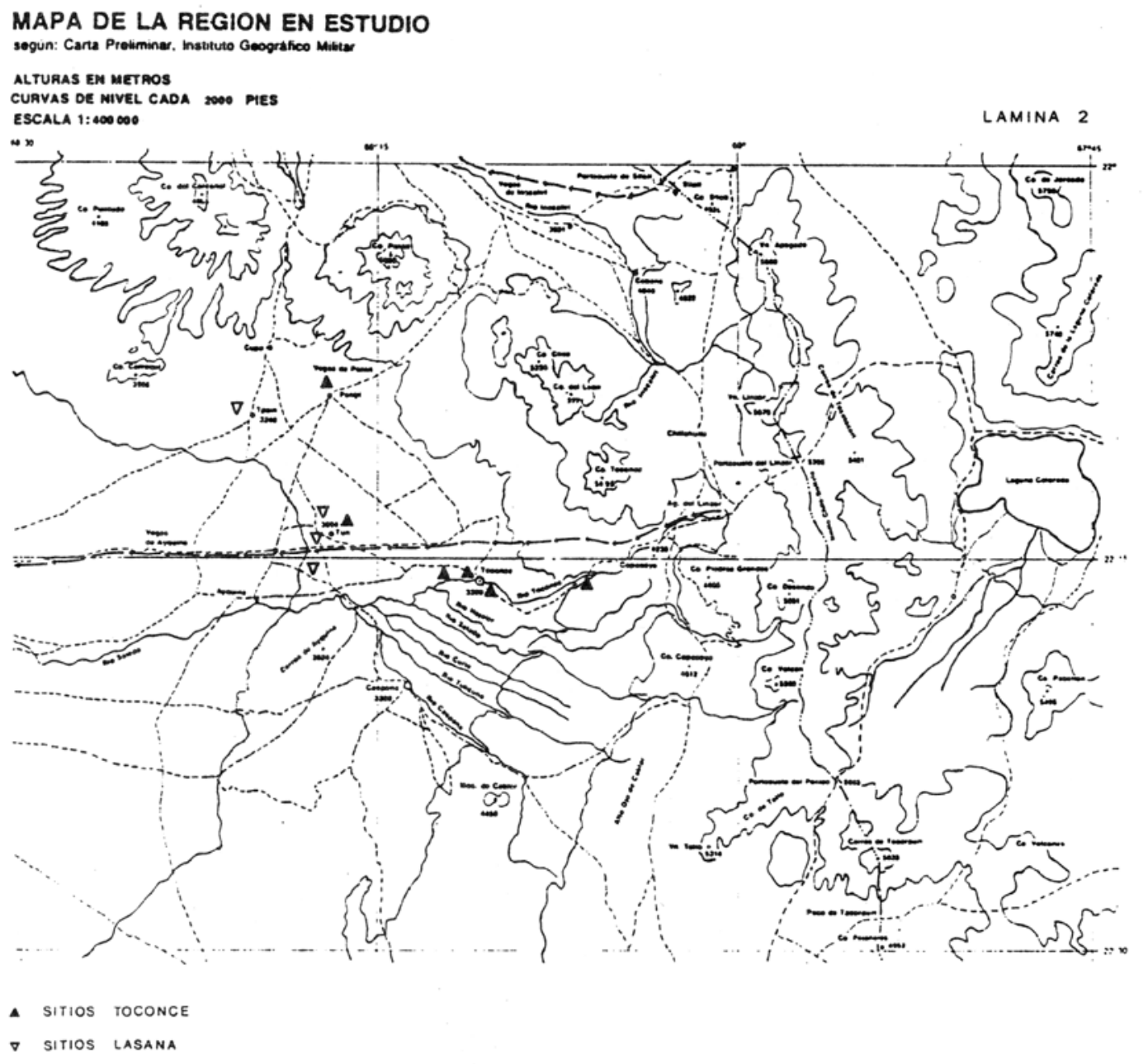

Figura 2. Sitios Toconce y Lasana en la cuenca del río Salado durante el Período Intermedio Tardío (Castro et al. 1984).

especial se dirige en esta década hacia un cambio cualitativo, particularmente respecto del género de inferencias que se comienzan a hacer a partir de los datos arqueológicos. Pese a sus omisiones respecto a las chullpa hay que reconocer que el trabajo de Pollard constituyó, sin duda, un esfuerzo inédito por enfocar regionalmente la arqueología del Loa Medio y Superior, y que los trabajos de Núñez en diferentes puntos del norte de Chile facilitaron enormemente la revaluación de la problemática regional. En cuanto al "control vertical de un máximo de pisos ecológicos" o "verticalidad", éste representó un cambio de paradigma (Leone 1972: 15-16) dentro de la antropología andina y, como todo nuevo paradigma, hizo que los arqueólogos se enfrentaran a los sitios y materiales arqueológicos de una manera radicalmente diferente. Difícilmente encontraremos un ejemplo más claro de las consecuencias de este cambio de paradigma en la arqueología andina que el producido en nuestra región. En efecto, su advenimiento hizo que los arqueólogos vieran los mismos sitios y materiales del Loa Superior -conocidos de la década del 50 $o$ antes - de manera totalmente distinta a como los habían visto hasta entonces. Núñez, por ejemplo, que en 1965 no había podido integrar a las chullpa de Toconce (Likan) dentro de su esquema de desarrollo cultural prehispánico para el norte de Chile 
(Núñez 1965b), una década más tarde reconoce en ellas a una forma de penetración desde las tierras altas, de carácter colonial, altiplánico y tardío (Núñez et al. 1975: 24). Es que los estudios de Murra entregaron a la arqueología un instrumento de análisis inapreciable para comprender las "operaciones del hombre, cultura y sociedad andina" (Núñez y Dillehay 1979: iii y 6). En 1977, cuando la mencionada publicación de Núñez y colaboradores aún no se conocía, llevamos al VIII Congreso de Arqueología Chilena una ponencia en la que sosteníamos una idea similar. Nuestro planteamiento partía reconociendo que el sitio Likan presenta elementos "atacameños" y "altiplánicos", pero que se trata de una colonia de este último origen, asentada en el Salado "con algún tipo de control vertical de la ecología" (Castro et al. 1979: 478 y 493). Que dos grupos de investigadores lleguen a una misma conclusión en forma independiente, no es algo demasiado raro, aunque sin duda contribuye a dar mayor certeza a la hipótesis. Lo importante es que el prisma de la "ecocomplementariedad" otorgó sentido a muchos restos arqueológicos de la región que, en ausencia de él, quizás habrían permanecido sin encajar quién sabe cuánto tiempo más.

En suma, la antigua tesis de una penetración de "culturas altiplánicas" tardías en la cuenca del río Salado, intuida primero por Hanson, insinuada luego por Mostny y defendida más tarde por Le Paige, emerge renovada en la segunda mitad de los años 70, aunque bajo la inspiración de las ideas de Murra y sustentada en viejas y nuevas evidencias. Las nuevas evidencias corresponden a lo que hemos formalizado como Fase Toconce, cuya definición y caracterización son materia del siguiente apartado.

\section{La Fase Toconce}

\section{Los sitios}

Los sitios de la Fase Toconce estudiados por nosotros se hallan en dos localidades arqueológicas: el valle del Toconce y la vega de Paniri. En el primero se encuentran los sitios de Likan (el más grande de la fase), Quebrada Seca, Chulqui, Melcho y Potrero; y en la segunda, el sitio de Paniri (el siguiente en tamaño después de Likan). Descripciones de Likan se hallan en Castro y colaboradores (1979a) y Aldunate y colaboradores (1982). Los otros sitios han sido descritos en Aldunate y Castro (1981) (Figura 2).
Sospechamos que hay varios sitios más pertenecientes a esta fase arqueológica en las quebradas afluentes del río Salado, pero no lo hemos comprobado. De hecho, Le Paige (1959: 115-124) dice que hay chullpa en los actuales pueblos de Ayquina y Caspana. Si bien Núñez y Dillehay (1978: 108) reiteran que en Ayquina hay chullpa, nosotros no hemos podido encontrarlas. En cuanto a las de Caspana, parece ser que Le Paige se refiere al muy cercano sitio de Talikuna (Le Paige 1965: Lám. 31, abajo; Núñez y Dillehay 1979). Lo que sí es factible, es que tanto Ayquina como Caspana, y quizás también Cupo, sean pueblos construidos a expensas de ruinas de la Fase Toconce preexistentes en el lugar. Le Paige (Ms), por ejemplo, anota en su diario que el actual pueblo de Caspana fue "establecido sobre el antiguo, del cual no queda ningún vestigio". En el caso del actual pueblo de Toconce, Le Paige hace notar que su emplazamiento enfrente de las ruinas (Likan), y no encima de ellas, permitió su conservación. En general, los actuales pueblos indígenas parecen haber sido instalados sobre o en las proximidades de las ruinas prehispánicas tardías, tal como, por lo demás, se dice que ocurrió en Lípez (Berberián y Arellano 1980). Por esta razón, la probabilidad de que obliteraran o destruyeran total o parcialmente las ruinas de los asentamientos de la Fase Toconce es, desgraciadamente, muy alta.

Otro sitio de chullpa mencionado por Le Paige (1963: 23) es el de Quihusuma, el cual tampoco hemos podido encontrar; ni siquiera hemos logrado dar con el topónimo en el mapa. Tal vez se halla en otra subregión.

Basados en la distribución que muestran hoy los asentamientos etnográficos, intuimos que también hay sitios Toconce en las quebradas altas de la vecina Subregión del río San Pedro, aunque, por analogía con sus contrapartes actuales, suponemos que deben ser más pequeños y atípicos. ${ }^{7}$ En la Subregión del Alto Loa, en cambio, pese a que hemos prospectado sistemáticamente algunos de sus sectores (Berenguer et al. 1975), no se han registrado hasta ahora sitios definitivamente atribuibles a esta fase. Y en la región del Loa Medio, la sugerencia de Núñez y Dillehay (1979) en orden a que en el cementerio de Los Antiguos, en Lasana, hay enterramientos

\footnotetext{
7 Es importante no confundir al río San Pedro, de esta región, con el río homónimo que pasa por el pueblo de San Pedro de Atacama.
} 
altiplánicos relacionables con lo que ahora definimos como Toconce, es extremadamente interesante, pero requiere de una más cuidadosa verificación.

En este recuento es importante no dejar de mencionar al componente altiplánico presente en el Pucara de Turi, cuya filiación Toconce es evidente a través de las chullpa que hay en la parte más alta de la fortaleza (Mostny 1949: 170-172) y por medio de algunos contextos funerarios recuperados de las tumbas por Spahni (1964: 6).

\section{El asentamiento-tipo}

En general, los sitios de la Fase Toconce suelen estar emplazados en las laderas de las quebradas, adaptándose a la topografía abrupta del talud de escombros formado en los cañones y extendiéndose muchas veces hasta la cima, en donde el relieve se convierte en "mesas" o en suaves lomajes. El asentamiento-tipo es marcadamente diferente al de las fases contemporáneas Lasana II y San Pedro IV, y consta de tres áreas muy bien definidas: área de poblado, área de chullpa y área de depósitos.

El poblado se emplaza siempre en un área más baja que las otras, rara vez sobre el piso mismo de la quebrada, pero sí, muchas veces, sobre el mencionado talud de escombros del cañón. En un sitio de la fase puede haber entre 20 y 200 unidades residenciales, las que suelen disponerse en un patrón aglutinado o de muros contiguos. Por lo general, estos recintos presentan una planta rectangular, una superficie nivelada artificialmente para neutralizar la fuerte pendiente del talud y muros simples hechos de piedras de campo puestas unas sobre otras sin argamasa. Los vanos de acceso a los recintos están formados por dos piedras verticales y otra horizontal en la base a modo de umbral. Estos vanos comunican recintos contiguos o dan a vías de circulación que conectan los diferentes puntos del poblado. No se han observado ventanas. En ocasiones, los muros posteriores de los recintos tienen pequeños nichos cuadrangulares semejantes a hornacinas. Sobre la superficie de las unidades residenciales hay grandes morteros y una enorme cantidad de desperdicios, preferentemente trozos de cerámica y pequeños litos modificados.

El sector de chullpa, en cambio, ocupa siempre el lugar más alto del asentamiento, aunque algunas de sus estructuras pueden encontrarse a veces en medio del poblado. La construcción más característica de este sector y de toda la arquitectura de la Fase Toconce es naturalmente la chullpa, una estructura en forma de torre, con muros simples o dobles hechos de piedras unidas con argamasa, planta circular, ovalada o rectangular, y con un pequeño vano cuadrangular al pie y, con mayor frecuencia, a media altura del muro (Aldunate y Castro 1981; Aldunate et al. 1982; Berenguer et al. Ms). Estas estructuras guardan mucha similitud con las torres funerarias de la Subárea Circumtiticaca (Aldunate y Castro 1981), pero en este caso no se trata de cámaras funerarias, sino de adoratorios (Aldunate et al., 1982). El número de chullpa en los distintos sitios de la fase es variable; los hay con no más de 20 de estas estructuras y otros con más de 80 . Para mayores detalles sobre la función de estas chullpa ver Aldunate y colaboradores (1982) y para su relación con el culto de los cerros, Berenguer y colaboradores (Ms).

El sector de depósitos, finalmente, se encuentra en la línea de ruptura entre el talud y la pared del cañón. Allí la naturaleza ha formado en la roca cavidades de diferente tamaño - probablemente agrandadas en forma artificial-, las que han sido tapadas con muros de piedras unidas con argamasa, dejando una abertura cuadrangular virtualmente idéntica al vano de las chullpa. Este es un sector funcionalmente ambiguo, ya que en la mayoría de los sitios dichas estructuras han sido empleadas como lugares de almacenaje de productos agrícolas, en cambio en el sitio Likan han sido utilizadas como sepulturas. Localmente, estas estructuras son conocidas como "trojas", de manera que nosotros al describirlas hemos optado por discriminar entre "trojas agrícolas" y "trojas funerarias". 8

Vale la pena señalar, aunque sea de paso, que el arte rupestre asociado a las ruinas de la Fase en Likan se halla en las paredes rocosas del cañón, muchas veces en línea con las "trojas". Se compone de pinturas y grabados de camélidos, figuras serpentiformes e individuos con atavíos y tocados relativamente elaborados.

\section{Patrón funerario y contextos}

Tal como se anticipó al describir el asentamientotipo, era costumbre entre los miembros de la Fase

8 Agradecemos a John Murra el habernos sugerido esta distinción conceptual. 
Toconce depositar a sus muertos en pequeños abrigos rocosos tapados con un muro, estructura cuya apariencia es absolutamente idéntica a la de los silos o "trojas agrícolas". Aunque la ambigüedad entre tumbas y silos no es privativa de Toconce en la Subárea Circumpuneña (Latcham 1938; Rydén 1944; Mostny 1969), la estructura que se construye para tumba/silo sí es peculiar de la fase. Estas "trojas funerarias" operaban a veces como tumbas individuales, pero en general eran colectivas.

Los primeros arqueólogos que vieron el cementerio de Likan encontraron las tumbas seriamente removidas. No obstante, los informantes más ancianos del pueblo de Toconce dicen que antiguamente había cadáveres sentados adentro de estas "trojas". Atribuyen el saqueo de estas tumbas a "gringos" venidos de Chuquicamata. Nuestras excavaciones, en tanto, han demostrado que, en muchos casos, la remoción postdepositacional sólo afectó a la superficie de las sepulturas. Debajo suelen encontrarse verdaderas capas de enterramientos, con los huesos -en ocasiones- dispuestos sin posición anatómica. Tenemos la impresión de que los cadáveres eran colocados originalmente en posición sedente, tal como los habrían visto los ancianos de Toconce, pero que con el correr del tiempo probablemente se iban desarticulando y cayendo a la superficie de la cámara funeraria. Con la introducción de nuevos cadáveres, los restos de los más antiguos irían quedando paulatinamente obliterados por los más recientes, acumulándose en capas como las que hemos tenido ocasión de excavar arqueológicamente. ${ }^{9}$

Mostny y Naville (1957) sostuvieron tempranamente que estas tumbas colectivas eran familiares, hipótesis que posteriormente hemos podido comprobar. En efecto, Quevedo (Ms) encontró en una de estas tumbas a varios individuos con una patología hereditaria -la condromatosis múltiple-, circunstancia que sugiere fuertemente que los usuarios de una "troja funeraria" en particular tenían entre sí lazos familiares y que el

9 Cuando Bastien (1973: 259-260) describe la "jornada a la Uma Pacha” en el ritual mortuorio Qollahuaya relata un episodio que es congruente con nuestra hipótesis. Dice que al estar excavando la fosa para enterrar a un difunto, encontraron sucesivamente dos osamentas humanas (una de ellas bastante reciente), que correspondían a inhumaciones de la comunidad. Naturalmente, la analogía no incluye otros aspectos del patrón funerario Toconce. uso de estas estructuras aparentemente era privativo de un linaje específico. ${ }^{10}$

Debido a que las tumbas eran, por lo visto, periódicamente abiertas para introducir nuevos cadáveres y tal vez para pasearlos en ceremonias como las que describen los cronistas para Perú, los materiales funerarios de la fase no provienen de "contextos cerrados". Se trata, más bien, de "contextos abiertos", disturbados no sólo por miembros de la Fase Toconce, sino por indígenas posteriores que, al parecer, las emplearon ocasionalmente como tumbas hasta hace muy poco tiempo. La actividad de los "huaqueros" y, más recientemente, de los arqueólogos, ha venido a completar este cuadro de disturbaciones postenterratorias.

Los ofertorios funerarios incluyen los siguientes ítems:

- Cabezas humanas separadas del cuerpo.

- Restos de cestería coiled conteniendo semillas de algarrobo y chañar.

- Trozos de calabazas pirograbadas (Castro et al. 1979b: Lám. I, 11-15).

- Cajitas de madera (Castro et al. 1979b: Foto 2, Fig. 3).

- Tabletas y tubos para inhalar polvos psicoactivos. ${ }^{11}$

10 Estamos manejando la misma idea para el caso de las chullpa.

11 Debemos a C. Torres (com. pers. 1983) la siguiente información sobre las tabletas procedentes de Toconce. En el Museum of the American Indian, Heye Foundation, Nueva York, hay siete tabletas (y un tubo) bajo el rótulo de "cuevas río Toconce", donadas por Earl Hanson: 14/3738, 14/3739, 14/3740, 14/3741 (tubo), 14/3742, 14/3743, 14/3744 y 14/3745. En el Museo Nacional de Historia Natural de Santiago (Chile), hay seis tabletas y 10 tubos, donados por G. Kunsemüller en 1959: las tabletas tienen los números 14965, 14970, 14971, 14972 (fragmento), 14973 (de piedra) y 14974; los tubos están numerados del 14980 al 14989. En el Museo Arqueológico R. P. Gustavo Le Paige hay dos tabletas sin número (una con dos cabezas de felino y la otra con una sola). La información dejada por Le Paige sobre estos artefactos se encuentra en el volumen dedicado a Toconce (p. 4), de la biblioteca del Museo y dice lo siguiente: "Las tabletas para rapé son muy interesantes a pesar que varias son únicamente rectangular con la cabeza estilizada del puma. Pero una es de piedra. Otra tiene como escultura el Sacerdote con la tiara a doble medialuna y tocando la flauta a tres notas, igual al personaje central de la tableta para ofrenda del sacrificio del niño de Caspana. Otra tiene dos animales de frente que parecen vampiros". "Los tubos para rapé son muy variados, el sacerdote enmascarado con la hacha y la cabeza cortada, dos personajes encuclillados 
- Espátulas de madera y hueso (Castro et al. 1979b: Foto 3, Figs. 1-4).

- Palas líticas (Castro et al. 1979b: Foto 1, Fig. 1) y de madera (Castro et al. 1979b: Foto 2, Fig. 1; Spahni 1964: Figs. 2-22).

- Un fragmento de kero retrato de madera.

- Cuentas discoidales de mineral de cobre.

- Ganchos de atalaje (Castro et al. 1979b: Foto 2, Fig. 2).

- Cerámica Hedionda Negro sobre Ante (Castro et al. 1979b: Lám. I; Spahni 1964: Foto 7 izq. y Figs. 2-20).

- Agujas de cactus y metal.

- Punzones y cuchillones curvos de madera.

- Vasijas cerámicas en miniatura.

- Conchas de almeja y ostión.

- Alfileres de cobre.

- Litos esferoidales con acanaladura anular (¿boleadoras?)

- Torteras de cerámica.

- Flautas de pan (cañas).

\section{La cerámica y su distribución}

El complejo cerámico de la fase comprende tres grupos diferenciados por el tratamiento y/o acabado dado a sus superficies: alisados, pulidos y decorados con pintura.

El grupo "alisados" incluye los tipos Likan Ordinario Alisado y Likan Rojo Alisado. ${ }^{12}$ El primero es un tipo que a veces presenta un alisado tan rudimentario, que en una o en sus dos superficies se observan rugosidades, estrías irregulares y pequeñas oquedades, probablemente por desplazamiento de los materiales duros de la pasta con el instrumento alisador. En otros casos, la superficie carece de estas imperfecciones, aunque a través de ella se alcanza a ver al antiplástico y son notorias también las huellas del instrumento alisador. El color de la superficie va de café rojizo a café gris, pasando por tonalidades naranja. La coc-

juntos mirando del mismo lado, de una parte un hombre y de la otra como un camaleón”. Este material, según Le Paige, habría sido recogido por la "expedición científica del Centro de Arqueología de Chuquicamata". Más adelante, Le Paige indica un hallazgo hecho posteriormente por "una persona de Antofagasta": una flauta de pan de cuatro notas en forma escalonada y una tableta para rapé con cabeza de puma y recipiente redondo (según C. Torres, hay fotos de estos dos objetos en el archivo del Museo).

12 El Likan Ordinario Alisado fue mencionado en otra parte como "tipos ordinarios" (Aldunate y Castro 1981: 135). ción es oxidante, de regular a mala. El antiplástico es grueso (1 a $2 \mathrm{~mm}$ ) y el espesor de los fragmentos alcanza hasta los $5 \mathrm{~mm}$. Aparentemente, se trata de grandes vasijas con asas (aunque también parece haber algunas más pequeñas), de boca restringida, cuerpo globular y base plana. El tipo Likan Rojo Alisado está representado por fragmentos con el exterior revestido por un engobe rojo opaco, aplicado generalmente mediante un baño. El interior suele estar solamente alisado, aunque hay casos en que también se observa la aplicación de un engobe, si bien de color negro o gris oscuro. La muestra no es muy abundante y los fragmentos son excesivamente pequeños, siendo muy escasos los bordes. Da la impresión de que, en la mayoría de los casos, se trata de escudillas, aunque algunos fragmentos fuertemente inflexionados sugieren formas más complejas. Las características de la pasta son muy similares al Likan Ordinario Alisado.

El grupo "pulidos" incluye los tipos Dupont Negro Pulido y Ayquina Café Pulido. ${ }^{13}$ No vale la pena extenderse en la descripción de estos tipos, ya que fueron descritos con anterioridad por otros autores (Núñez 1965b; Orellana 1968). Es suficiente recordar que en el primer caso se trata de escudillas con el exterior alisado y el interior negro engobado y pulido. Por lo general, el engobe de Dupont se encuentra craquelado. En el segundo caso, se trata también de escudillas con el exterior alisado y el interior engobado y pulido, pero los colores son café-gris, café-rojo o rojo. Además, en el tipo Ayquina es común una acanaladura anular en el borde, la presencia de estrías de pulimento, la ausencia de craquelado en el engobe y la existencia de fragmentos pulidos, pero sin engobe.

El grupo "decorados con pintura" se compone de un solo tipo, el Hedionda Negro sobre ante (Castro et al. 1979a: Lám. 1). Los fragmentos de este tipo tienen la superficie cubierta por un delgado engobe de color ante (crema), aunque a veces se encuentran fragmentos sin engobe alguno, pero con la superficie de ese mismo color. ${ }^{14}$ Las caras interna y externa presentan un pulido homogéneo. La cocción es

13 Estos tipos fueron mencionados preliminarmente bajo la denominación "familia regional" (Aldunate y Castro 1981: 134-135).

14 Hay fragmentos que, en lugar de un fondo ante o crema, presentan una base roja. Ignoramos si corresponden a una variante de este tipo o constituyen un tipo cerámico por sí 
VICTORIA CASTRO, CARLOS ALDUNATE, JOSE BERENGUER

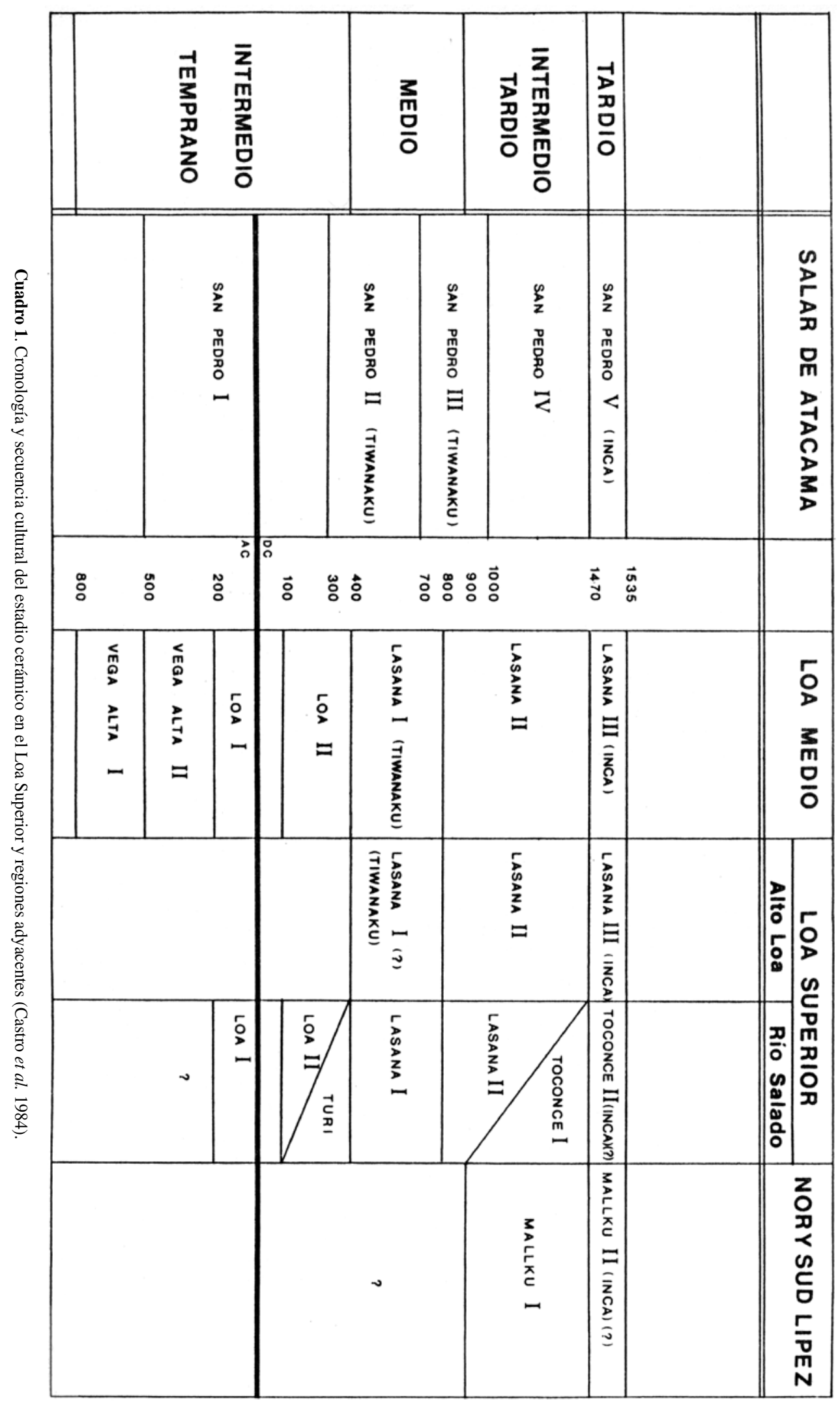


oxidante y muy buena. La pasta tiene un color muy similar al de la superficie y generalmente contiene un desgrasante finísimo compuesto de trozos de cerámica. Predominan en este tipo los labios planos, pero también los hay redondeados o convexos. El estudio de formas indica que se trata de escudillas hemisféricas, con bordes rectos y divergentes (rara vez ligeramente evertidos), de paredes más o menos altas y base plana. El campo de decoración es el borde interno y/o externo, comprendiendo una variedad de diseños geométricos negros (pintura café, en realidad), tales como volutas, grecas, líneas serpenteantes entre paralelas, líneas serpenteantes entrecruzadas formando rombos u óvalos, líneas de las cuales cuelgan otras a modo de guirnaldas, etc. El labio también se usa a veces como campo de decoración, pintándose toda su superficie con una línea continua o pintándose sobre él segmentos de líneas dispuestas perpendicularmente a la trayectoria de su circunferencia.

El complejo cerámico presente en los sitios de la Fase Toconce aparece asociado a varias otras cerámicas de escasa significación cuantitativa en la muestra (Aldunate y Castro 1981: 136). Es el caso, por ejemplo, de fragmentos negro pulidos por ambas caras y de fragmentos negro alisados también por ambas caras. Unos pocos fragmentos alisados y pintados de color rojo podrían ser asimilados al tipo San Pedro Rojo Violáceo (Orellana 1963) y otros decorados con pintura negra sobre un slip blanco sin pulir son, sin duda, exponentes del tipo Huruquilla (Ibarra Grasso 1957: 334).

Analizando la distribución en el norte de Chile de la cerámica presente en Toconce, se concluye que muchos tipos no son privativos de sitios de esta fase. La mayor dispersión la tiene el tipo Huruquilla, de muy débil frecuencia en la cuenca del río Salado y con similitudes estilísticas no bien estudiadas con el tipo Taltape de los Valles Occidentales. Aparece esta cerámica en Pica Tardío (Núñez 1976: 113), Caleta Huelén 12 (Núñez 1971: 23), Dupont 1 (Núñez 1965b: 75), Coyo (Le Paige 1964: 66), Solcor (Le Paige 1964: 81), Solor 4 (Le Paige 1964: 84),

mismo. En todo caso, su peso cuantitativo es insignificante dentro del universo total de la muestra. y Quitor 9 (Le Paige 1964: Lám. 148, Fig. 1). Otro tipo de amplia distribución es el Dupont. Desde luego está en el sitio-tipo. Orellana (1968) lo registra en Chiu Chiu, Turi, Ayquina y Caspana. Núñez (1965b), por su parte, al describir el Complejo Pica, encuentra una cantidad suficiente de fragmentos de este tipo como para sugerir “contactos Dupont”. El mismo Núñez (1971) menciona el hallazgo de esta cerámica en Quillagua, así como en un tramo de la costa que va desde la desembocadura del río Loa hasta Taltal. Referencias sobre este tipo cerámico en San Pedro de Atacama se encuentran en Bittmann y colaboradores (1978), Núñez (1976) y Orellana (1963). En este mismo volumen Tarragó dice que la cerámica Dupont "también se da en el borde oriental como es el caso del alto valle Calchaquî́". Una distribución similar parece tener el llamado "complejo de los baños rojos", ya que su extensión abarca un triángulo que tiene como vértices a Pica, San Pedro de Atacama y Taltal. Este "complejo" está todavía muy poco estudiado y al parecer reúne bajo una misma denominación a muchas cosas distintas. En todo caso, pareciera que el tipo Lasana Rojo Alisado (Núñez 1965b) es básicamente lo mismo que nuestro tipo Likan Rojo Alisado. Con relación al tipo Ayquina, Orellana (1968: 17) lo registra "a lo largo de todo el río Salado (Toconce, Caspana, Turi, Ayquina, Chiu Chiu y Calama)"; agrega que este tipo también está en Lasana, en varios yacimientos de San Pedro de Atacama (Pucara de Catarpe, Solor, Vilama y Coyo), en Peine y en la costa de Antofagasta. Por nuestra parte, hemos hallado esta cerámica en Topaín, cerca de Cupo, y en varios sitios habitacionales y ceremoniales del Alto Loa. Por lo tanto, el tipo Ayquina, aun cuando presenta algunos registros en la costa de Antofagasta, parece estar confinado únicamente al interior de la II Región y según Orellana (1968) su centro de distribución estaría en la cuenca del río Salado. Pollard (1970: 312), en cambio, dice que el análisis petrográfico de los fragmentos cerámicos, hecho por Lanning, demostró que todas las vasijas manufacturadas localmente y encontradas en sitios Lasana II de Chiu Chiu, Lasana, Santa Bárbara, Topaín, Turi y Ayquina fueron hechas con arcillas que sólo se encuentran en Chiu Chiu y Lasana. Entendemos que esto también vale para el tipo Ayquina. Finalmente, está el caso de la cerámica Hedionda. Si nos olvidamos de las opiniones -todavía poco fundamentadas- que proponen asimilar este 
tipo al Chilpe, habría que reconocer que Hedionda es la cerámica de menos dispersión en el norte de Chile, de todas las que componen el complejo cerámico de la Fase Toconce. Supuestamente está en San Pedro de Atacama, bajo la denominación de "Colla-Pacajes" (Le Paige 1964: 81, 84 y 85) y también en el Loa Medio (Thomas com. pers. 1983), pero, sobre todo, se encuentra en los sitios tardíos de la cuenca del río Salado. ${ }^{15}$

Adicionalmente, es posible sugerir que el tipo Likan Ordinario Alisado es una cerámica exclusivamente local, pero no hay manera de comprobar esto por el momento. Las descripciones que se requerirían para un cotejo adecuado entre cerámicas llanas del resto del norte de Chile y este tipo, son por ahora inexistentes.

\section{Cronología y secuencia}

Hay varios indicadores que contribuyen a situar el desarrollo de la Fase Toconce en la primera mitad de este milenio. Por lo pronto, la chullpa es uno de estos indicadores, puesto que, al menos en el Area Centro Sur Andina, se las atribuye a los períodos Intermedio Tardío y Tardío (Hyslop 1976: 91 y 109; Aldunate y Castro 1981; Aldunate et al. 1982). Otro buen indicador es la calabaza pirograbada. En la Subárea Circumpuneña, este artefacto se populariza hacia los inicios del Intermedio Tardío y constituye un excelente marcador cronológico del período. En San Pedro de Atacama, por ejemplo, aparecen en contextos funerarios preincaicos de Catarpe 2, 3 y 4 (Le Paige 1964: 86-89 y Láms. 154-158). Los tipos cerámicos Dupont y Hedionda, por su parte, sirven igualmente como marcadores cronológicos generales del Período Intermedio Tardío. El tipo Dupont, sobre todo, ha sido muy bien situado cronológicamente en otros sitios de la Subárea Circumpuneña. ${ }^{16}$ La ubicación del tipo Hedionda,

15 Pollard (Ms) ilustra varios fragmentos clasificables como Hedionda, que proceden de sitios fortificados como RAnL300 (Pucara de Turi), RAnL-299 (Topaín), RAnL-1 (Pucara de Lasana) y RAnL-99 (Pucara de Chiu Chiu), así como de sitios de "muros y cajas", tales como RAnL-261, RAnL-348A, RAnL-298 y otros. Todos estos sitios, como se sabe, han sido atribuidos por Pollard (1970) a Lasana II.

16 En la capa d(3) del Alero Toconce, un sitio estratificado excavado previamente por Orellana (1971) y reexcavado recientemente por nosotros, se encontró cerámica Dupont, la que en cambio, se basa, por una parte, en correlaciones estilísticas de larga distancia con la Fase Kekerana de la Subárea Circumpuneña, que tienden a situarla ca. 1100 DC (Lumbreras y Amat 1968). ${ }^{17} \mathrm{Y}$ por otra, se basa en dataciones directas e indirectas por termoluminiscencia, tal como veremos enseguida.

La cronología absoluta de la Fase Toconce ha sido hecha únicamente sobre la base de fechados por termoluminiscencia (TL). Estas fechas se distribuyen entre los años 910 y 1210 DC, guardando correspondencia con los indicadores culturales mencionados previamente (Cuadro 2). ${ }^{18}$

Tenemos buenas razones, sin embargo, para pensar que el desarrollo de la Fase Toconce se prolonga hasta una fecha que podría fijarse en $c a$. $1450 \mathrm{DC}$. Nos basamos para esto en que las muestras que rindieron fechas TL más recientes (p.e., IFUC-5) provenían de niveles más profundos que $30 \mathrm{~cm}$, ya que en esa época el laboratorio IFUC sostenía que "las mejores muestras son aquellas que han sido encontradas a una profundidad de a lo menos $30 \mathrm{~cm}$ " (Castro et al. 1979b: 8). Como es fácil

\footnotetext{
fue fechada en 1070 \pm 60 años radiocarbónicos (Beta-1991), $880 \pm 60$ DC. En Quitor 9, una tumba con cerámica Dupont

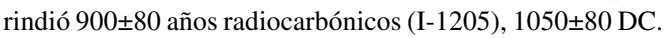
Estas dos fechas son tempranas para esta cerámica, pero pensamos que su data es aún más antigua. Con respecto a sus dataciones más tardías en la región, se dispone de dos fechas: 460 \pm 100 años radiocarbónicos (IVIC-171), $1490 \pm 100$ DC para una tumba del sitio-tipo (Dupont 1 o Chunchurí) y 480 \pm 50 años radiocarbónicos (Beta-7319), $1470 \pm 50$ DC para el final de una ocupación Lasana II en el poblado de Quinchamale (SBa-119), en el Alto Loa.

17 Según L. Lumbreras (com. pers. 1983), la ubicación de la Fase Kekerana comenzando alrededor de 1100 DC, puede modificarse o retrotraerse. Lumbreras dice que su ubicación cronológica está referida a la fecha tope propuesta para el fin de las influencias de Tiwanaku, de modo que obedece a un esquema de periodificación y no a fechados absolutos.

18 Algunos fechados TL de la Fase Toconce resultaron inesperadamente tempranos, en relación a las postulaciones cronológicas que se han hecho en la Subárea Circumtiticaca para sitios similares con chullpas (Lumbreras y Amat 1968; Hyslop 1976). Hemos conversado sobre este problema con E. Mujica y L. Lumbreras y ambos han estado de acuerdo en que los fechados son coherentes con los últimos planteamientos sobre la cronología en el lago Titicaca. Mujica (com. pers. 1983) nos ha dicho que los sitios con chullpas en la Subárea Circumtiticaca pueden ser, perfectamente, más tempranos que 1100 DC, apreciación ratificada también por Lumbreras (com. pers. 1983).
} 


\begin{tabular}{|l|c|c|c|c|c|l|}
\hline \multicolumn{1}{|c|}{ Muestra } & Recinto & Capa & Prof. cm & Fecha estimada & Fecha TL & Observaciones \\
\hline IFUC-5 & X-2 & III & 35 & $1100-1400$ DC & 1210 DC & Cerám. Dupont \\
\hline IFUC-0 & X-2 & III & 40 & 1200 DC & 1077 DC & \\
\hline IFUC-1 & X-157 & III & 60 & $1100-1200$ DC & 1030 DC & \\
\hline IFUC-4 & X-157 & III & 62 & $1000-1100$ DC & 910 DC & Cerám. Hedionda \\
\hline IFUC-2 & X-157 & III & 66 & $800-1100$ DC & 980 DC & \\
\hline
\end{tabular}

Cuadro 2. Fechados absolutos para la Fase Toconce.

apreciar, estos "a lo menos $30 \mathrm{~cm}$ " superiores de los depósitos arqueológicos -no fechados por TL ni por ningún otro método- podrían corresponder a 250 años de ocupación o quizás más, suponiendo que la velocidad de sedimentación en la mitad superior del depósito sea aproximadamente la misma que en la inferior. Esto situaría el término de la Fase Toconce prácticamente en la víspera del arribo de los incas a la región.

La fase cultural inmediatamente más temprana en el Loa Medio es Lasana I (400-800 DC), que también está presente en el sitio multicomponente RAnL-351, a unos $300 \mathrm{~m}$ al norte de los Baños de Turi (Pollard 1970: 298). Durante el Período Intermedio Tardío, por otra parte, coexisten en la planicie semidesértica de Turi -a la vista uno de otros- los asentamientos Lasana II y Toconce. Es el caso, por ejemplo, de Topaín y Paniri, respectivamente. Incluso hay una situación muy sugerente en el Pucara de Turi, puesto que aun cuando sus componentes preincaicos han sido atribuidos a Lasana II, la parte más alta de la fortaleza aparece coronada de chullpa. Todavía no estamos en condiciones de establecer la secuencia de los acontecimientos en Turi, precisando, por ejemplo, si los miembros de la Fase Toconce ocuparon la fortaleza con anterioridad a los incas o sólo lo hicieron una vez que éstos arribaron a la región. Algunos indicios dan para pensar lo primero, ya que para construir el explazo en donde edificarían la kallanka los incas debieron despejar una gran superficie del pucara que estaba repleta de otras construcciones, algunas de las cuales parecen haber sido chullpa. En todo caso, la posibilidad de un episodio de aculturación incaica de esta fase arqueológica en Turi, designable como Toconce II, es por ahora solamente especulativa (ver Cuadro 1).

\section{El estado actual del problema}

En el pasado, la Subárea Circumpuneña fue escenario de un interesante proceso cultural, en el cual las sociedades de cazadores recolectores locales lograron niveles de vida cada vez más desarrollados, recibiendo, además, fuertes estímulos culturales del altiplano, de los bosques orientales y probablemente de otras regiones aún no identificadas, y debiendo convivir con pueblos venidos de muchos lugares. Desde la quebrada de Tarapacá hasta el alto valle Calchaquí, pasando por el río Loa, el Salar de Atacama y la Puna de Jujuy, se desarrollaron más tarde numerosos complejos, todos los cuales estuvieron culturalmente adaptados a un mismo o a un muy similar medio ambiente. La red de intercambio consolidada en esta subárea durante el primer milenio de nuestra Era -pese a las interferencias altiplánicas de Tiwanaku- no hizo sino acentuar las afinidades culturales que se habían ido produciendo entre los complejos como consecuencia de sus experiencias comunes. De hecho, se popularizaron una serie de elementos culturales que, más que ser patrimonio de un complejo circumpuneño en particular, pasarían a caracterizar a la subárea en su totalidad. Es el caso, por ejemplo, de las calabazas pirograbadas, cencerros de madera, ganchos de atalaje, instrumentos agrícolas de madera, túnicas, escudos y petos de cuero, capachos, armas de cobre y de bronce, algunos tejidos y cestos, implementos del "complejo alucinógeno", cerámica monocroma y tantos otros ítems. Pese a las diferencias específicas entre estos complejos culturales, que sin duda son notorias, las investigaciones arqueológicas llevadas a cabo durante la primera mitad de este siglo repararon tan sólo en aquellos "elementos generalizados", produciendo una historia cultural de "grano grueso" que tendió a interpretar todo esto como el producto de una sola cultura. Tal es, al parecer, la naturaleza arqueológica de lo que los arqueólogos originalmente denominaron "cultura atacameña" (Núñez et al. 1975: 9; Núñez 1976: 194).

En la actualidad, la palabra "atacameño" debiera reservarse en arqueología para denominar a toda la tradición cultural que se desarrolló en el bioma 
desértico de la Subárea Circumpuneña. Esta tradición atacameña incluye varios complejos culturales que se desarrollaron en la Subárea Circumpuneña al mismo tiempo y/o en diferentes épocas. Algunos de estos complejos interactuaron fuertemente con otros pertenecientes a tradiciones vecinas.

\section{La Fase Toconce y los complejos del desierto}

Creemos que este último es el caso de la Fase Toconce. En efecto, cuando Mostny (1959) analiza los contextos funerarios de las sepulturas en abrigos rocosos de Toconce (Likan) y, contrariamente a sus expectativas, concluye que son "típicamente atacameños", lo que está haciendo es reconocer la presencia de aquellos "elementos generalizados" de lo que acabamos de definir como tradición atacameña, pero en un sitio con arquitectura altiplánica. Por encontrarse en el borde de su propia tradición e interactuando constantemente con los complejos del desierto, es explicable que la Fase Toconce haya incorporado a su patrimonio cierta ergología "típicamente atacameña", de la misma forma que los complejos del desierto incorporaron cerámica Hedionda. El carácter mobiliar de estos ítems sin duda contribuyó decisivamente en la naturaleza selectiva de estas transferencias. El patrón funerario de Likan, en cambio, es ajeno a la subárea, cuestión que es extremadamente sugestiva para la tesis de un origen altiplánico de la Fase Toconce. Son circunstancias como éstas, precisamente, las que nos llevan a pensar que los miembros de la Fase Toconce no eran grupos originarios del desierto.

Por de pronto, ya es un hecho relativamente establecido que los individuos de la Fase Toconce deformaban sus cabezas de una manera diferente a como lo hacían sus contemporáneos del complejo San Pedro. Los cráneos del cementerio de Likan estudiados por Quevedo y Cocilovo presentan una clara y muy pronunciada deformación tabular erecta, con algunos varones exhibiendo deformación circular. Quevedo (com. pers. 1983) nos ha señalado que los cráneos referidos carecen de la plagiocefalia o deformación poco típica que afecta al lambda, rasgo que por otra parte se encuentra generalizado en los cráneos de San Pedro IV. ${ }^{19}$ Por el momento, ignoramos cómo se manifiesta este aspecto en otros complejos vecinos, pero ya es sumamente sugestivo que la población

19 La Fase IV de San Pedro en este trabajo corresponde a la Fase III establecida por Orellana (1963a). de la Fase Toconce deforme sus cabezas de una manera distinta y más cuidada que la población de uno de los complejos del desierto más próximos a ella. Esta singularidad podría estar reflejando la naturaleza intrusiva de la población Toconce en la Subárea Circumpuneña, aunque no constituiría prueba alguna de su origen altiplánico. ${ }^{20}$

El único elemento que, hasta ahora, ha demostrado una real capacidad diagnóstica en este último sentido es la chullpa. ¿Pero basta la presencia de chullpa en un sitio tardío para atribuirle inmediatamente una filiación altiplánica? Digamos que es una condición necesaria, pero no suficiente. Hasta donde sabemos, las chullpa no forman parte de la tradición cultural dominante en esta subárea (Núñez et al. 1975: 24), de manera que su presencia en sitios tardíos es indispensable para evaluarlos arqueológicamente como altiplánicos. Sin embargo, hay muchas formas mediante las cuales la arquitectura de una tradición puede aparecer en sitios pertenecientes a otra. Por eso, junto con las chullpa es preciso que aparezcan asociados otros elementos, formando una asociación específica o "configuración altiplánica".

\section{Correlaciones con la Subárea Circumtiticaca}

Ciertamente, la chullpa no es el único elemento de Toconce extraño a la Subárea Circumpuneña. También lo son el patrón de asentamiento y la escudilla de dos colores. La asociación recurrente de estos tres elementos en los sitios es lo que llamamos una "configuración" y el carácter "altiplánico" se lo da el hecho de que estos elementos están entre los más característicos del período en los desarrollos del lago Titicaca (Tschopik 1946; Hyslop 1976). Dichos elementos bien podrían equivaler a la contraparte altiplánica de aquellos elementos generalizados que discrimináramos en la tradición atacameña.

Como la Fase Toconce parece no tener precedentes en el Loa Superior ni en otras regiones de la Subárea Circumpuneña y, por otra parte, algunos de sus elementos más conspicuos también se encuentran en el altiplano nuclear, es razonable plantear que sus orígenes más remotos están en alguna región

\footnotetext{
20 Todas las "naciones" andinas se diferenciaban por sus trajes (Cobo 1964), pero también lo hacían por sus tocados (y deformaciones cefálicas), y este es un rasgo distintivo de gran importancia. Rostworowsky (1983: 122) se refiere a las deformaciones cefálicas entre los collahuas y cavana conde como indicadores étnicos (J. Martínez com. pers. 1983).
} 
de la Subárea Circumtiticaca. Sabemos bien que estos planteamientos despiertan cierta reticencia en algunos colegas, especialmente cuando sugerimos que la región de origen puede ser la de Omasuyo. En realidad, el problema del origen ex situ de la Fase Toconce requiere un tratamiento sumamente cuidadoso. Desde luego, hay que tener presente que cualquier área específica que se sugiera como lugar de origen de la fase representa, en el mejor de los casos, únicamente la región con mayor probabilidad de serlo en el estado actual de las investigaciones. Es necesario reiterar también que nuestra base de comparación no son elementos aislados, sino un conjunto de ellos que aparecen en el registro arqueológico recurrentemente asociados, lo cual deja menos lugar para explicar las similitudes de detalle mediante la casualidad o por contactos históricos indirectos. Y por último, la idea de una supuesta relación entre la Fase Toconce y alguna fase regional del Omasuyo no implica insinuar que entre ellas existió algún tipo de sujeción, sino solamente sugerir que ambas fases pueden haber tenido un origen común en otra fase precedente aún no identificada, radicando una en el noreste del Titicaca y emigrando la otra hacia el Altiplano Meridional. ${ }^{21}$ Recalcamos que ésta es una hipótesis de trabajo que requiere una muy cuidadosa comprobación y que por mientras debe ser manejada con la mayor cautela y amplitud de criterio.

Se nos ha preguntado (no sin cierta razón) por qué, en lugar de Omasuyo, no pensar en Tanka Tanka o en Lípez como puntos de origen de la Fase Toconce, ya que allí hay cerámica muy parecida a la Hedionda. El problema es que en Tanka Tanka sólo la cerámica presenta semejanzas de detalle con Toconce. Lípez, por su parte, presenta un problema especial que debe ser interpretado de otra manera, tal como pasaremos a exponerlo más adelante. En cambio, las similitudes de detalle con la región de Omasuyo incluyen: a) chullpa de piedra relativamente bajas, vano a media altura del muro, interior estrecho, construcción menos elaborada en relación a las del resto del lago (McBain 1959) y sin función de sepulturas; b) sepulturas individuales y colectivas en abrigos rocosos, con muros de piedras adosados a la cavidad y un pequeño vano cuadrangular a la manera de las chullpa (Nordenskiold 1953; Rydén 1957; McBain 1959), patrón funerario que es diferente al

21 Esta idea modifica un planteamiento que hiciéramos más tempranamente, respecto de la sujeción de Toconce a un supuesto reino asentado en las riberas norte y noreste del lago Titicaca (Aldunate y Castro 1981: 169). de chullpa y cistas prevaleciente en otras regiones del Titicaca (Tschopik 1946; Bennett 1948); y c) una variedad de la serie cerámica Khonko Kollau (Bennett 1948; Lumbreras 1974; Núñez 1976), representada en el Loa Superior por el tipo Hedionda Negro sobre Ante (Castro et al. 1979a) y en el Titicaca por el tipo que Tschopik (1946) denominara Sillustani Marrón sobre Crema, el cual según esta autora y Bandelier (McBain 1959) es más popular en el Omasuyo y según Lumbreras y Amat (1968; Lumbreras 1974) integra la fase cerámica Kekerana, de esa misma región.

La distancia que hay entre el Loa Superior y la región de Omasuyo podría restar factibilidad a nuestra hipótesis. Pero las comparaciones basadas en un conjunto de ítems arqueológicos han sido reconocidas desde hace mucho tiempo como una forma de evidencia, a través de la cual es posible evaluar relaciones culturales entre dos áreas. En ningún caso se sostiene que este género de comparaciones sea infalible, aunque una separación de aproximadamente $1000 \mathrm{~km}$ no es tan grande como para que impida postular comparaciones válidas, máxime si los complejos culturales involucrados pertenecen a una misma tradición.

Existe un área en el altiplano, sin embargo, en donde las similitudes con los materiales de la Fase Toconce son más estrechas que en ninguna otra parte, incluyendo a la región de Omasuyo. Nos referimos al Departamento de Potosí y, específicamente, a las provincias de Nor y Sud Lípez.

\section{Correlaciones con Lípez}

Una de las mayores novedades para nuestra investigación fueron los hallazgos hechos por Berberián y Arellano (1980) en el noreste de la Subárea Circumpuneña, poco más al sur del salar de Uyuni y precisamente en el borde meridional de la provincia boliviana de Nor Lípez. Si bien tales hallazgos no representaron propiamente una sorpresa, ya que con mucha anticipación Barfield (1961) había encontrado cerámica Hedionda en un alero de la laguna epónima y Le Paige (Ms) había registrado esta misma cerámica en Peña Barrosa y Quetena, en este caso la similitud con la Fase Toconce abarcaba un mayor número de ítems, cuestión que la hacía especialmente novedosa. Además, sus autores establecían las mismas relaciones que hacemos nosotros con la región de Omasuyo y la Fase Kekerana (Arellano y Berberián 1981: 60 y 74-76). Estas investigaciones 
se habían estado realizando en el sur de Bolivia en forma paralela a las nuestras y a poco más de 80 $\mathrm{km}$ de la localidad de Toconce.

Arellano y Berberián (1981: 53) formalizaron sus hallazgos con la denominación Mallku, interpretándolos como los restos de un señorío de pastores-cultivadores supuestamente aymara, que se habría desarrollado en Lípez en tiempos post-Tiwanaku y previos al Tawantinsuyo. La designación Mallku corresponde al sitio-tipo, el que, a su vez, recibe el nombre de la cercana localidad de esa denominación. Los trabajos han consistido en prospecciones muy extensivas, sondeos exploratorios y excavaciones en tumbas individuales y colectivas (Arellano y Berberián 1981: 51). Aparte del sitio-tipo, se han encontrado materiales atribuibles a Mallku en sitios localizados en la cercanía de los ríos Quetena y Grande de Lípez, tales como Mallku Abajo, Río Quetena, Puka Pucara, Quebrada Mulatos y Zoniquera.

Las similitudes entre Mallku y Toconce incluyen:

- Chullpa similares en todo a las de Toconce (Arellano y Berberián 1981: 60-62 y 68), incluso la chullpa que se muestra en la Foto 2 es idéntica a nuestro tipo D (Aldunate y Castro 1981: 119).

- Ausencia de restos humanos en el interior de las chullpa (Arellano y Berberián 1981: 62; Arellano com. pers. 1983), aunque en su artículo los autores asumen que tienen la misma funcionalidad funeraria que la mayoría de las chullpa del Titicaca (Arellano y Berberián 1981: 60-62).

- Ofrenda de fragmentos de palas líticas, inhumadas en el interior de las chullpa (Arellano y Berberián 1981: 56; Aldunate et al. 1982: 152).

- Sepulturas individuales y colectivas en abrigos rocosos con muro de piedras adosado a la cavidad (Arellano y Berberián 1981: 60-62; Aldunate et al. 1982: 147-148).

- Muros de circunvalación en colina con reducto de cumbre (Arellano y Berberián 1981: 58-60 y Fig. 2; Aldunate et al. 1981: 148-149).

- Calabazas pirograbadas (Arellano y Berberián 1981: 64 y Foto 3; Castro et al. 1979a: Lám. 1, 11-15).
- Cesto en forma de escudilla, hecho con técnica coiled (Arellano y Berberián 1981: 69; Castro et al. 1979a: Fotos 2-5).

- Escudillas cerámicas del tipo denominado por los autores Mallku Marrón sobre Crema (Berberián y Arellano 1980; Arellano y Berberián 1981: 7176 y Figs. 4-10), idéntica al tipo Hedionda Negro sobre Ante (Castro et al. 1979a: Lám. 1, 1-10).

Salvo las calabazas pirograbadas y la cestería coiled cuya distribución se halla generalizada en la Subárea Circumpuneña, el resto son ítems o rasgos altiplánicos. En el estado actual de los estudios, cualquiera de estos ítems aparecidos en Mallku podría ser colocado junto a materiales Toconce y nadie sería capaz de identificar cuáles son de una fase y cuáles de otra. Considerando tan estrechas similitudes entre desarrollos culturales producidos en lugares tan próximos entre sí, poca duda cabe que Mallku y Toconce son parte de un mismo complejo cultural. Por esta razón, la sugerencia de que el origen de la Fase Toconce podría estar en Lípez (léase Mallku), es incorrecta. Nos asiste la mayor convicción de que las similitudes abarcarán en el futuro un mayor número de ítems ya que las excavaciones en Lípez han sido hasta ahora muy reducidas. Cabe esperar, igualmente, que con la intensificación de las prospecciones arqueológicas, tanto en Lípez como en el Salado, no pasará mucho tiempo antes de que se disponga de una idea completa sobre la distribución de los sitios Toconce-Mallku en la Subárea Circumpuneña.

El problema de la identidad étnica

Con respecto a la filiación étnica de los materiales arqueológicos de la Fase Toconce y al destino de estas comunidades altiplánicas con posterioridad al arribo de los incas, debe señalarse que la investigación se encuentra recién en sus comienzos. Hace más de medio siglo, Hanson (1926: 377) sostuvo que después de una ocupación "atacameña" y con posterioridad a la llegada de Diego de Almagro, se habría asentado en la cuenca del Salado una población "no-atacameña" venida de Bolivia, la que sería el ancestro de los indígenas quechua o aymara parlantes que residen actualmente en Ayquina, Toconce y Caspana. Su hipótesis es básicamente correcta, por lo menos al identificar un sustrato "atacameño" y una población altiplánica posterior. Pero los predecesores "atacameños" de los cuales habla Hanson (aquellos que fundían cobre en la 
vega de Turi y a orillas del río Toconce), seguramente no son los mismos que nosotros consideramos como tales y que adjudicamos a Lasana I (sitio RAnL-351; Pollard 1970); y los presuntos ancestros "no atacameños" de la población indígena actual, evidentemente son distintos a los que nosotros estimamos como sus predecesores llegados desde el altiplano. El problema está en que la población venida de Bolivia no arribó recién después de Almagro, como sugiere Hanson, sino mucho antes, siendo responsable de los restos arqueológicos que hoy atribuimos a la Fase Toconce. Tampoco es seguro que constituya el ancestro de la población indígena moderna, al menos no en un sentido directo, ya que los movimientos de poblaciones producidos durante el Tawantinsuyo originan muchas interrogantes a este respecto.

Núñez (1976: 187), en tanto, sugirió que las chullpa de Toconce (Likan) y demás localidades vecinas constituyen una manifestación arqueológica de los Lípez, un grupo étnico de la región epónima que aparece mencionado en fuentes documentales de los siglos XVI y XVII. La inferencia parece tener su base en las propias chullpa y en la proximidad de estos restos arqueológicos al territorio en que supuestamente vivieron estos indígenas. Núñez sugiere, además, que durante el Período Intermedio Tardío los Lípez habrían estado organizados como un "reino altiplánico menor o señorío", análogo, hasta cierto punto, a los "reinos" lacustres de más al norte, documentados mediante la etnohistoria y la arqueología.

Por nuestra parte, desde 1977 veníamos sugiriendo que los ocupantes de Likan podrían corresponder a alguna etnia aymara sin entrar en mayores especificaciones. Nos basábamos para esto en dos hechos aparentes: primero, que las chullpa de la Subárea Circumtiticaca fueron vistas por los españoles en uso entre grupos que ahora conocemos genéricamente como aymara (Cieza 1945 [1550]: 257; Matienzo 1967 [1567]: 129), de manera que los usuarios de las chullpa de Toconce bien pudieron tener igual filiación étnica; y segundo, que una parte importante de la población actual de Toconce y localidades vecinas tiene apellidos y presenta costumbres de origen aymara, por lo tanto, era razonable sugerir que la población antecesora en la cuenca del Salado -portadora, como la actual, de varios elementos culturales altiplánicos- tuviese también ese origen étnico. Sin embargo, el problema dista mucho de ser tan nítido. En la medida en que hemos ido accediendo a la información etnohistórica que hay sobre las vecinas provincias de Nor y Sud Lípez, estamos ahora menos dispuestos a arriesgar afirmaciones tan categóricas (Aldunate et al. 1982: 129). ${ }^{22}$ Sobre todo sabiendo que algunas fuentes del siglo XVI hacen referencia no a uno, sino a varios grupos étnicos y a diversas lenguas en esas provincias. ${ }^{23}$ Por añadidura, se dice que el tronco lingüístico de los habitantes del Omasuyu -la supuesta región de origen de la Fase Toconce- no era el aymara (Lumbreras 1974), sino el pukina (Torero 1970).

Desde luego, nunca ha sido fácil visualizar a los complejos arqueológicos en términos de comunidades etnológicamente identificables. Pero, en este caso, creemos que la dificultad debe cargarse más a la cuenta de una falta de investigación que al problema mismo. Subsiste un panorama étnico muy confuso en la Subárea Circumpuneña y lo más aconsejable para el futuro inmediato es multiplicar las investigaciones en esta dirección.

\section{Sumario y conclusiones}

A menudo la Región del Loa Superior ha sido vinculada arqueológicamente al desarrollo "atacameño". Se ha demostrado aquí, sin embargo, que una de sus fases culturales, la de Toconce, difiere en importantes aspectos de los complejos de la tradición atacameña y un supuesto origen in situ de esta fase es, hoy por hoy, insostible. Las semejanzas de Toconce con la Subárea Circumtiticaca, en cambio, son tan estrechas, que es posible utilizarlas como una forma de evidencia para trazar relaciones culturales entre esa subárea y la Circumpuneña. Sobre estas bases, el problema de los orígenes altiplánicos de la Fase Toconce nos parece ahora una cuestión que esta más allá de cualquier duda. Podrá haber variaciones en el futuro, quizás porque su lugar de origen resulte estar en una región del lago Titicaca distinta a la de Omasuyo, pero difícilmente se modificará la

\footnotetext{
22 Por supuesto, esto no invalida el carácter altiplánico de la Fase Toconce y tampoco las analogías históricas directas con las que hemos trabajado últimamente (Aldunate et al. 1982; Berenguer et al. Ms). En el caso de éstas, las analogías se hacen más generales, sin dejar por ello de ser "históricas directas".

23 La reducción de los indios Lípez, en 1600, deja entrever la existencia de otros grupos, tales como los indios pululos, yalas y gemes, además de los Lípez (AGN Buenos Aires, Leg. 18: 6: 5-1600). Lozano Machuca (1885 [1581]: XXIII) señala por su parte que los pululos serían urus. Por último, un documento fechado en 1580 da cuenta de que mientras en Atacama se hablaba aymara, en Lípez las "lenguas generales" eran esta última y el uruquilla (AGI, Indiferente General 532 fs. 377v) (J. Martínez com. pers. 1984).
} 
idea de su pertenencia a la tradición altiplánica. En nuestra opinion, la Fase Toconce constituye una clara manifestación regional y reciente de esta extensa y vieja tradición, representando, probablemente, una de sus más australes intrusiones preincaicas en los flancos occidentales de los Andes.

Su identificación étnica es aún problemática, si bien hay indicios que sugieren que, tratándose de una etnia altiplánica, no es propiamente aymara. No es posible, empero, afirmar esto último en forma categórica.

Uno de los tópicos singularmente más intrigantes y quizás de mayor relieve que queda pendiente al concluir este artículo es la discusión acerca de los mecanismos adaptativos puestos en juego por esta población de origen altiplánico, al desplegar sus asentamientos tanto en las quebradas de la cuenca del Salado como en la puna trasandina de Lípez. En nuestro próximo trabajo abordamos este punto con cierto detalle. Anticipamos, en todo caso, que el Complejo Toconce-Mallku acusa, a través de su patrón de asentamiento, un manejo muy "altiplánico" de la idea de complementariedad ecológica. No obstante, entrevemos el uso de soluciones adaptativas peculiares, que confieren cierta originalidad a esta interesante implantación humana en la Subárea Circumpuneña.

Agradecimientos Nuestro primer reconocimiento es para el Departamento de Desarrollo de la
Investigación de la Universidad de Chile, que con su permanente financiamiento ha hecho posible nuestras investigaciones a lo largo de estos años. Deseamos agradecer también al Consulado de los EE.UU. en Santiago, especialmente a su Agregado Cultural, Sr. Guy Burton, quien nos consiguiera varias publicaciones de indispensable consulta. A Constantino Torres, becario de postdoctorado de Fullbright, por haber tenido la amabilidad de facilitarnos información sobre tabletas para alucinógenos de Toconce, que se encuentran en distintos museos del país y el extranjero. A Gordon Pollard (State University of New York), quien gentilmente nos enviara dos de sus trabajos, uno de ellos inédito. También estamos sumamente agradecidos de Luis G. Lumbreras y Elías Mujica (Instituto Andino de Estudios Arqueológicos), así como de John V. Murra (Cornell University), por sus interesantes comentarios críticos al planteamiento central de este escrito. Nuestro reconocimiento incluye, muy especialmente, a Fernando Maldonado, por su trabajo topográfico e ilustrativo, a Silvia Quevedo (Museo Nacional de Historia Natural), por su estudio del material óseo humano y a José Luis Martínez (Museo Chileno de Arte Precolombino), por sus informaciones sobre la etnohistoria del área. Estamos particularmente agradecidos de la comunidad de Toconce, cuya hospitalidad, cooperación y paciencia ha hecho de nuestro trabajo de campo una experiencia no solamente exitosa, sino tambien extremadamente grata.

\section{REFERENCIAS CITADAS}

ALDUNATE, C. y V. CASTRO, 1981. Las chullpa de Toconce y su relación con el poblamiento altiplánico en el Loa Superior. Período Tardío. Ediciones Kultrún, Santiago.

ALDUNATE, C., J. BERENGUER y V. CASTRO, 1982. La Función de las chullpas de Likan. Actas del VII Congreso de Arqueología Chilena (Valdivia 1979), pp. 129-174. Ediciones Kultrún, Santiago.

ALDUNATE, C., J. BERENGUER, V. CASTRO y J. L. MARTINEZ, Ms. El Complejo Toconce-Mallku: Una adaptación altiplánica en la Subárea Circumpuneña.

ARELLANO, J. y E. BERBERIAN, 1981. Mallku: El señorío postTiwanaku del Altiplano Sur de Bolivia. Bulletin de l'Institut Français d'Etudes Andines 10 (1-2): 51-84.

BARFIELD, L., 1961. Recent discoveries in the Atacama Desert and the Bolivian Altiplano. American Antiquity 27: 93-101.
BASTIEN, J. W., 1973. Qollahuaya rituals: An ethnographic account of the symbolic relations of man and Land in an Andean village. Cornell University, Doctoral Thesis published on demand by University Microfilms International, Ann Arbor.

BENNETT, W., 1946. The Atacameño. Handbook of South American Indians, J. H Steward (Ed.). Bulletin 143 (2): 599-618, Washington D. C.

1948. A revised sequence for the South Titicaca Basin. American Antiquity 13 (2): 90-92.

BERBERIAN, E. y J. ARELLANO, 1980. Desarrollo cultural prehispánico en el Altiplano Sur de Bolivia. Provincias Nor y Sud Lípez, Depto. Potosí. Revista do Museu Paulista Nova Série 27.

BERENGUER, J., V. CASTRO y C. ALDUNATE, Ms. Orientación orográfica de las chullpa en Likan: La importancia de los 
cerros en la Fase Toconce. Simposio Culturas Atacameñas, $44^{\circ}$ Congreso Internacional de Americanistas (Manchester 1982). En prensa.

BERENGUER, J., F. PLAZA, L. RODRIGUEZ y V. CASTRO, 1975. Reconocimiento arqueológico del río Loa Superior. Sector Santa Bárbara, Boletín de Prehistoria de Chile 7-8: 59-97.

BERTRAND, A., 1885. Memorias sobre las cordilleras del Desierto de Atacama y regiones limítrofes. Imprenta Nacional, Santiago.

BITTMANN, B., G. LE PAIGE y L. NUÑEZ, 1978. Culturas atacameñas. Editorial Gabriela Mistral, Santiago.

CASTRO, V., J. BERENGUER y C. ALDUNATE, 1979a. Antecedentes de una interacción altiplano-área atacameña durante el Período Tardío: Toconce. Actas del $7^{\circ}$ Congreso de Arqueología de Chile (Altos de Vilches 1977), pp. 477498. Ediciones Kultrún, Santiago.

CASTRO, V., C. ALDUNATE, J. BERENGUER y otros, $1979 \mathrm{~b}$. Primeros fechados arqueológicos por termoluminiscencia en Chile: Toconce (II Región). Noticiario Mensual del Museo Nacional de Historia Natural 270: 3-10.

CIEZA DE LEON, P., 1945 [1553]. La crónica del Perú. Espasa Calpe, Buenos Aires.

COBO, B., 1964 [1653]. Historia del Nuevo Mundo. Biblioteca de Autores Españoles, vols. 91-92, Madrid.

CONGRESO INTERNACIONAL DE ARQUEOLOGIA DE SAN PEDRO DE ATACAMA, 1963. Resúmenes de Actas. Anales de la Universidad del Norte 2: 187-206.

DURAN, E., 1976. Calabazas pirograbadas del Departamento del río Loa y sus correlaciones con areas vecinas. Actas y Memorias del $4^{\circ}$ Congreso Nacional de Arqueología (San Rafael 1974), vol. 3: pp. 119-126. Mendoza.

HANSON, E., 1926. Out-of-the-world villages of Atacama. Geographical Review 16: 365-377.

HYSLOP, J., 1976. An archaeological investigation of the Lupaqa Kingdom and its origins. Columbia University, Doctoral Thesis published on demand by University Microfilms International, Ann Arbor.

IBARRA GRASSO, D. E., 1957. Nuevas culturas arqueológicas de los antiguos indígenas de Chuquisaca, Potosí y Tarija. Arqueología Boliviana, Primera Mesa Redonda, pp. 235-285. Biblioteca Paceña-Alcaldía Municipal, La Paz.

LATCHAM, R. 1938. Arqueología de la región atacameña. Prensas de la Universidad de Chile, Santiago.

LEONE, M., 1972. Issues in anthropological archaeology. Contemporary archaeology, M. Leone (Ed.), pp. 14-27. Southern Illinois University Press, Carbondale y Edwardsville.
LE PAIGE, G., 1959. Antiguas culturas atacameñas en la cordillera chilena, Anales de la Universidad Católica de Valparaíso 4-5.

1963. Continuidad o discontinuidad de la cultura atacameña. Anales de la Universidad del Norte 2: 7-25.

_- 1964. El Precerámico en la cordillera atacameña y los cementerios del Período Agroalfarero de San Pedro de Atacama. Anales de la Universidad del Norte 3.

__ 1965. San Pedro de Atacama y su zona. Anales de la Universidad del Norte 4.

_ Ms. Diario de Terreno. Toconce, Laguna Hedionda y Peña Barrosa.

LOZANO MACHUCA, J., 1885 [1581]. Carta del Factor de Potosí Juan Lozano Machuca al virrey del Perú, en donde se describe la provincia de los Lípez, 8-XII-1581. Relaciones Geográficas de Indias Perú, vol. 2, Madrid.

LUMBRERAS, L., 1974. Los reinos postTiwanaku en el área altiplánica. Revista Museo Nacional de Lima 40: 55-87.

LUMBRERAS, L. y H. AMAT, 1968. Secuencia arqueológica del altiplano occidental del Titicaca. Actas del $37^{\circ}$ Congreso Internacional de Americanistas (Buenos Aires, 1966), vol. 2 , pp. 75-106. Buenos Aires.

McBAIN, H., 1959. The Adolph Bandelier archaeological collection from Pelechuco and Charazani. Revista del Instituto de Antropología.

MATIENZO, J., 1967 [1567]. Gobierno del Perú. Edición de G. Lohman. Travaux de l'Institut Français d'Etudes Andines, París, Lima.

MOSTNY, G., 1949. Ciudades atacameñas. Boletín de Museo Nacional de Historia Natural 24: 125-211.

1959. Una colección de Toconce. Noticiario Mensual del Museo Nacional de Historia Natural 35.

_ 1969. Ideas mágico-religiosas de los "atacamas". Boletín del Museo Nacional de Historia Natural 30: 129-145.

MOSTNY, G. y R. NAVILLE, 1957. Le Complexe de chullpa de Toconce (Chili). Bulletin de la Société Suisse des Americanistes 13.

MURRA, J., 1972. El control vertical de un máximo de pisos ecológicos en la economía de las sociedades andinas. Universidad Hermilio Valdizán, Huánuco.

NEVILLE, R., 1956. Sur les traces de J. J. de Tschudi dans le Desert d'Atacama. Bulletin de la Société Suisse des Americanistes 12: 18-30.

NORDENSKIOLD, E., 1953. Investigaciones arqueológicas en la región fronteriza de Perú y Bolivia. Biblioteca PaceñaAlcaldía Municipal, La Paz. 
NUÑEZ, L., 1963. Problemas en torno a la tableta de rapé. Anales de la Universidad del Norte 2: 149-168.

- 1965a. Prospección arqueológica en el norte de Chile. Estudios Arqueológicos 1: 9-35.

- 1965b. Desarrollo cultural prehispánico en el norte de Chile. Estudios Arqueológicos 1: 37-115.

1971. Secuencia y cambios de los asentamientos humanos de la desembocadura del río Loa. Boletín de la Universidad de Chile 112: 3-25.

— 1976. Registro regional de fechas radiocarbónicas del norte de Chile. Estudios Atacameños 4: 74-123.

NUÑEZ, L. y T. DILLEHAY, 1979. Movilidad giratoria armonía social y desarrollo en los Andes Meridionales: Patrones de tráfico e interacción económica (ensayo). Universidad del Norte, Antofagasta.

NUÑEZ, L., P. NUÑEZ y V. ZLATAR, 1975. Relaciones prehistóricas trasandinas entre el nororiente argentino y norte de Chile (Período Cerámico). Serie Documentos de Trabajo 6: 1-25.

ORELlANA, M., 1963a. La Cultura San Pedro. Arqueología Chilena 3: 3-42.

- 1963b. Problemas de la arqueología de San Pedro de Atacama y sus alrededores. Anales de la Universidad del Norte 2: 29-39.

_ 1965. Informe de la Primera Fase del Proyecto Arqueológico Río Salado. Antropología Año III, pp. 81-117.

_ 1968. Tipos alfareros de la zona del río Salado. Boletín de Prehistoria de Chile 1: 3-21.

1971. Excavaciones en la confluencia de los ríos Toconce y Salado Chico. Boletín de Prehistoria de Chile 2-3: 119-136.

ORELLANA, M., C. URREJOLA y C. THOMAS, 1969. Nuevas investigaciones en río Salado. Actas del $5^{\circ}$ Congreso Nacional de Arqueología (La Serena 1969), pp. 113-127. Santiago.

OYARZUN, A., 1935. Instrumentos de caza y guerra en los antiguos atacameños. Actas del $26^{\circ}$ Congreso Internacional de Americanistas vol. 1, pp. 217-229. Sevilla.

POLLARD, G., 1970. The cultural ecology of ceramic stage settlement in the Atacama Desert. Columbia University,
Doctoral Thesis published on demand by University Microfilm International, Ann Arbor.

— Ms. Artifact illustrations originally intended for "prehistory and desert adaptation in Northern Chile.

QUEVEDO, S. Ms. Segundo informe bioantropológico de sepulturas en abrigos rocosos de la localidad de Toconce.

ROSTWOROWSKY, M., 1983. Estructuras andinas de poder ideología religiosa y política. Instituto de Estudios Peruanos, Lima.

RYDEN, S., 1944. Contributions to the archaeology of the rio Loa región. Elanders Boktryckeri Aktiebolag, Göteborg.

1957. Andean excavation I: The Tiwanaku Era east of the lake Titicaca. Publication of the Ethnographical Museum of Sweden 4.

SCHAEDEL, R., 1957. Informe general sobre la expedición a la zona comprendida entre Arica y La Serena. Arqueología Chilena 1: 5-76.

SPAHNI, J.C., 1963. Tombes inédites du cimétieres Atacamenien de Chiu Chiu (Chili). Bulletin de la Société Suisse des Americanistes 26: 2-9.

1964. Fouilles archeologiques dans deux cimétieres indigenes de Turi, Desert d'Atacama. Bulletin de la Société Suisse des Americanistes 27: 2-20.

TARRAGO, M., 1968: Secuencias culturales de la etapa agroalfarera de San Pedro de Atacama (Chile). Actas del $37^{\circ}$ Congreso Internacional de Americanistas (1966), pp. 119144. Buenos Aires.

1983. La historia de los pueblos circumpuneños en relación con el altiplano y los Andes Meridionales. Actas del Simposio de Arqueología Atacameña (1983). San Pedro de Atacama.

TORERO, A., 1970. Lingüística e historia de la sociedad andina. Anales Científicos 8 (3-4): 231-264.

TSCHOPIK, M., 1946. Some notes on the archaeology of the Department of Puno, Peru. Papers of the Peabody Museum of American Archaeology and Ethnology, Harvard University 27 (3).

UHLE, F. M., 1913. Los indios atacameños. Revista Chilena de Historia y Geografía V (9): 105-111. 